\title{
Getting Political Science in on the Joke: Using The Daily Show and Other Comedy to Teach Politics
}

Staci L. Beavers, California State University San Marcos

ABSTRACT The challenges of teaching introductory-level U.S. politics to reluctant audiences are well known and widely lamented. This article investigates the pedagogical potential of political satire, specifically The Daily Show with Jon Stewart, in engaging students in this tough-to-teach course. Based on a review of available literature and student survey data from the fall 2008 term, I argue that using this popular program in the classroom can enhance an introductory U.S. politics course. A review of both these survey data and student papers based on the program suggests promising possibilities for encouraging students' political engagement and critical-thinking skills. This preliminary examination demonstrates that further study on the program's potential both for student engagement and student learning outcomes is warranted.

ould comedians such as Jon Stewart, Tina Fey, and Stephen Colbert succeed where generations of political science professors and high school civics teachers have often struggled? Could such figures make it "cool" (or perhaps even "sweet," as my own young nephew might say) for young people to turn their attention to politics? Mainstream press coverage of popular political satire programs gives the impression that such potential exists (see, e.g., Peyser and Childress 2003; Stelter 2007).

The challenges of teaching introductory-level politics to reluctant audiences, in sections typically filled with students taking the course only to fulfill graduation requirements, are surely too well known to be trotted out again here. One approach that political science instructors might adopt to do our students and discipline a real service is to aggressively engage with our students' cultural reference points, particularly political comedy like that available in The Daily Show with Jon Stewart. Such an approach can help students engage with political events, issues, and analysis more easily and perhaps more willingly, making the discipline more accessible and "relevant" to these sometimes reluctant audiences. This method may also help us push students to approach and engage such popular culture venues critically, rather than remain as passive consumers.

My goal here is to examine the pedagogical potential of political satire, specifically The Daily Show with Jon Stewart, in the teaching of an introductory-level U.S. government course. I am hardly

Staci L. Beavers is an associate professor of political science at California State University San Marcos, where she teaches courses in U.S. politics and U.S. constitutional law. She has published previous work on political science pedagogy in PS: Political Science and Politics. She can be reached at sbeavers@csusm.edu. the first to suggest classroom use of political satire in general, or even this program in particular. Instead, I hope to offer an exploration of my own developing experimentation with such resources.

\section{COMEDY AND POLITICAL PEDAGOGY}

As any of us teaching today's introductory-level undergraduates can easily attest, capturing and keeping the attention of our young audiences are major challenges. Sources of competition for our students' attention in the classroom have mushroomed since the advent of "wi-fi" and cell phone texting, making some instructors nostalgic for the simple days of note-passing and whispering. Comedy venues such as The Daily Show combine often-sharp political commentary with attention-grabbing routines: as MacMullan observes, although Jon Stewart "certainly sacrifices a lot of intellectual street-cred for doing things like putting on a Geraldo mustache ... such bits let him educate an audience many times larger than that of any conventional intellectual" $(2007,58)$. Furthermore, MacMullan urges that intellectuals "study and emulate Jon Stewart if they want to be relevant to the public" (57).

A number of authors and scholars have made a serious case for humor as a critical tool in improving pedagogy. Norton (2001) opines that humor "can deliver a jolt of insight and excitement to a class of disconnected young people" and provide the "hooks" that will capture the audience's interest. Scholars from a number of disciplines share this view of humor's power as a motivating force in the learning process (for an overview, see Kher, Molstad, and Donahue 1999; see also Baumgartner and Morris 2008). Humor is touted as a force for building constructive classroom relationships that facilitate learning (Kher, Molstad, and Donahue 1999; Pollak and Freda 1997), and students in particular view humor 
as a key component of an effective teacher's repertoire for fostering student engagement (Weaver and Cottrell 1988, 23, 30-31). Other scholars credit humor for its positive effects on student retention of at least some materials (Kaplan and Pascoe 1977).

To date, the literature on comedy-infused pedagogy is sparse in the discipline of political science. The one published study I have identified that specifically examines humor in political science pedagogy (Baumgartner and Morris 2008) was only found well after I had collected the data discussed here. ${ }^{1}$ I find this paucity particularly disconcerting given the wealth of contemporary political comedy available for pedagogical uses. In building their own case for humor in the political science classroom, Baumgartner and Morris cite studies addressing political communication and entertainment (e.g., Baum 2002; Baum 2003a; Baum 2003b), but they come up short in identifying relevant political science literature that devotes attention to pedagogy. Instead, they assert that "there is no single disciplinary 'home' for scholars interested in humor" and "those interested in the effects of humor must cast a wide net to survey existing research" (2008, 174). Their own net ranges across fields from psychology to marketing to education (174-75), while research on humor in higher education pedagogy also tends to draw on such disciplines as conducted a quick examination of recent editions of introductory U.S. politics textbooks in my own collection and that of a colleague. I found little evidence that textbook authors were taking advantage of readily available cultural reference points found in political comedy. Of the 11 textbooks published between 2007 and 2009 that I examined, only one made more than cursory references to such comedy figures as Jon Stewart, Stephen Colbert, and Howard Stern, all formidable figures in American popular culture. One text, Janda, Berry, and Goldman's Challenge of Democracy (2009), displayed and discussed political cartoons in the front and back covers of the book, although none of these cartoons contained recognizable contemporary pop culture references. Ginsberg, Lowi, and Weir's We the People (2007) was unique in presenting a "Politics and Popular Culture" feature in multiple chapters, paying specific attention to such programs as Oprah and, of course, The Daily Show.

\section{POLITICS AND THE DAILY SHOW WITHJON STEWART}

Given that The Daily Show touts itself as being "unburdened by objectivity, journalistic integrity or even accuracy" (The Daily Show 2010), one might wonder how seriously anyone could possibly take the program? Apparently, very. In addition to its array of

\section{The Daily Show's clout is affirmed by its consistent array of influential guests for its regular interview segment, with top-level political officials frequently gracing Jon Stewart's guest chair. Intriguingly, the show has garnered high critical acclaim and elite participation while simultaneously capturing an audience critical to both advertisers and college professors: young adults. By 2006, 35\% of Pew survey respondents aged 18 to 29 indicated that they viewed the program "regularly" or "sometimes." For young men in this age group, that percentage rose to $40 \%$.}

psychology and communications-oriented disciplines (Korobkin 1988, 155).

The Baumgartner and Morris study of political comedy in the classroom is specifically based on an offshoot of Comedy Central's highly acclaimed The Daily Show with Jon Stewart. These scholars test the pedagogical potential of Jon Stewart, Ben Karlin, and David Javerbaum's America (the Book): A Citizen's Guide to Democracy Inaction (2004) as assigned class reading in several sections of their introductory-level U.S. politics course. In this quasi-experiment, Baumgartner and Morris do not find that students' reading, analysis, and discussion of this satirical work contribute to stronger performance on exams (179-80); however, survey results indicate that over $70 \%$ of the students assigned this book perceived the assigned reading as contributing to their learning (18o-81).

In my own case, a student's suggestion on a survey initially got me most intrigued about the possible use of The Daily Show in my introductory-level classroom. Having struggled in the past to reach reluctant students enrolled in this required general education course, and knowing that cluing myself into these ever-younger students' cultural reference points could only help me, I thought it was worth a shot to do some new homework of my own.

To gain a better sense of how (or whether) political comedy is being addressed in the discipline's introductory-level readings, I
Peabody and Emmy awards, the program won the 2003 Television Critics Association Award for Outstanding Achievement in News and Information, "edging out the work of the late NBC journalist David Bloom, Frontline, Nightline, and 60 Minutes" (Feldman 2007, 410). Ouch, indeed, if one is a "real" journalist who must compete for such an award against an oftdescribed "fake news show," let alone lose to one. The Daily Show's clout is affirmed by its consistent array of influential guests for its regular interview segment, with top-level political officials frequently gracing Jon Stewart's guest chair. Intriguingly, the show has garnered high critical acclaim and elite participation while simultaneously capturing an audience critical to both advertisers and college professors: young adults. By 2006, 35\% of Pew survey respondents aged 18 to 29 indicated that they viewed the program "regularly" or "sometimes." For young men in this age group, that percentage rose to $40 \%$ (Pew Research Center for the People and the Press 2006, 70). Although the program consistently provides sharp political commentary, research indicating the potential scope of the program's influence could raise some concerns. For example, one study has indicated that viewers under 30 "look to late night television comedy shows as a more credible source than traditional television news programs. A 2004 survey for the youth-engagement group Declare Yourself found that The Daily Show's Jon Stewart was more trusted than 
two of the three major networks' anchors" (Rottinghaus et al. 2008, 283).

Political pundit Bill O'Reilly may or may not have come to regret referring to Jon Stewart's viewers as "stoned slackers" (Erion 2007, 10), but while regular Daily Show viewers may be many things, politically ignorant is probably not one of their traits. In 2008, Pew survey respondents who counted themselves among The Daily Show's regular audience outscored not only those respondents who regularly watched The O'Reilly Factor on a political knowledge scale, but also viewers of several other TV news sources (Pew Research Center for the People and the Press 2008, 43-44). Partly to respond to concerns that late-night television programs such as The Daily Show had supplanted other sources of political information among the young, Young and Tisinger analyzed both Pew and National Annenberg Election Survey (NAES) data to argue that "late-night comedy viewers" also collect information from a variety of other news sources $(2006,128)$. However, a sizable portion of the young audience (approximately 61\% in the 2004 Pew survey; Pew Research Center for the People and the Press 2004, 11) has credited comedy programs as the source of at least some of their political information, so their perceptions may skew the argument in favor of political comedy's influence.

Another question about the influence of The Daily Show, particularly regarding its relevance for classroom use, is: to what extent does the program move beyond simply informing viewers to actually influencing their political views? Using a posttest-only experimental design, Baumgartner and Morris found that viewers exposed to The Daily Show expressed more skepticism regarding both major parties' nominees in the 2004 presidential race than people who were not exposed to the program $(2006,349)$. While these scholars expressed concern that watching the program might also increase viewers' "cynicism toward the electoral system and the news media at large" (341) and might discourage them from political involvement (362-63), the data indicated that these potentially more cynical viewers also exhibited a greater confidence in their own political comprehension (i.e., internal political efficacy). Baumgartner and Morris speculated that this higher confidence was due to the show's ability to "simplif[y] politics for its audience in a humorous manner," leading viewers to "feel validated in that they 'get' Jon Stewart's jokes" (353). As a counter to these scholars' concerns, Feldman reasons that because "young people who watch The Daily Show are also more knowledgeable about politics than non-viewers," they are not, after all, "disengaging from the political system as a result" of watching this program $(2007,423)$.

An additional question that is directly relevant to the use of The Daily Show in the classroom is: Can viewing the show really encourage students to want to learn more about politics? Certainly, if they want to get the jokes, yes (see Feldman 2007, 42223). One scholar asserts that watching entertainment-focused "soft news" can provide a "gateway" to paying greater attention to politics by exposing generally unengaged viewers to issues they might otherwise ignore entirely (Baum 2003 b, 48; also see Baumgartner and Morris 2008, 176). Additionally, Rottinghaus et al. cite evidence from their focus groups to express the hope that if "watching news presented in a humorous manner leads younger viewers to seek out other 'harder' sources of news, the impact of youth 'disaffection' concerning American politics may be assuaged" (2008, 293).
POSSIBLE RISKS OF ENGAGING STUDENTS VIA THE DAILY SHOW?

On the other hand, several cautions should be observed in thinking about The Daily Show's political humor as a teaching tool. Although Stewart and company's carefully edited clips of politicians' and media figures' statements often brilliantly point out inconsistencies and stories overlooked by other media outlets, do viewers (particularly those individuals with less independent information as context) always know how to sort out facts from exaggerations? For example, in the August 6, 2008, episode of The Daily Show, most viewers likely realized that former First Lady Rosalynn Carter never entered a recent beauty contest, as Jon Stewart asserted, but deliberate inaccuracies may confuse less wellequipped viewers. ${ }^{2}$ While the comedians' primary job is, of course, entertainment, and viewers must bear the responsibility of separating fact from fiction for themselves, how many viewers are able (or bother) to do so?

Baum (2002) has argued that "soft news" viewers pick up substantive information, however inadvertently, while viewing for their amusement or entertainment pleasure. While Zinser (2007, 46) describes the task of slipping news into entertainment as "sneaking vegetables onto a pizza," perhaps we should all be reminded of how easy it is to pick the healthy toppings off a pizza with one's fingers and simply eat the gooey, fattening parts that one actually likes; in other words, it may be too easy to ignore any real "substance" contained in light television programming to make much of a sustained difference in student learning or thinking (see Prior 2003).

Finally, the results of Baumgartner and Morris's 2007 study are also worth bearing in mind. This study found that collegeaged subjects who watched Stephen Colbert's bombastically conservative television character espouse his views on The Colbert Report tended to follow the drift of Colbert's faux conservative "argument" by moving (at least temporarily) straight to the right of the ideological spectrum in their political thinking.

In short, instructors who use such comedy must provide students with the tools they need to "get" the jokes and appreciate the humor while keeping the overarching objective of building critical-thinking skills firmly in mind.

\section{RESEARCH DESIGN}

In integrating political comedy into the fall 2008 section of my introductory-level U.S. politics course, I decided to (1) contextualize the use of political satire with explicit discussion of the concept and goals of my approach at the beginning of the semester; (2) ensure that the use of comedy clips in class was both steady and strategic; (3) include writing assignments in the curriculum that pushed students to analyze separate forms of political satire, including both political cartoons and television comedy in the form of The Daily Show; and (4) include various assessment components, including student surveys, to gauge student response to this approach.

To achieve the second goal, I devoted attention during the semester to both political cartoons and television comedy clips. Political cartoons were used periodically in class to illustrate theoretical concepts and launch discussions. With respect to television clips, I strove to make frequent but strategic use of brief comedy clips during the twice-weekly class meetings, fitting segments into the course as they related to topics under discussion. Looking back through my end-of-semester notes, I showed at least 
one brief clip of either The Daily Show or The Colbert Report not quite once every other week. While neither program's website is particularly serviceable in facilitating subject-oriented searches of its past episodes, The Daily Show website's current archiving of episode clips by date (as far back as 1999) can help users find old clips if they know exactly what they are seeking. Ultimately, by watching contemporary episodes and mining the shows' websites, I was able to find clips to jump-start discussion or illustrate concepts on a variety of topics. For example, both websites provided multiple clips regarding the Bush administration's policies on habeas corpus. Perhaps one of the most successful clips showed Stephen Colbert's July 27, 2006, interview with the Honorable Eleanor Holmes Norton. This particular clip provided context for a discussion of representation as a concept and congressional representation for the District of Columbia in particular. Not surprisingly, clips from these programs were most useful in facilitating discussions on current events, including the fall 2008 financial "bailout" plan. In short, my work keeping up with current episodes of the programs and mining the shows' respective websites provided relevant material for use in class.

To fulfill my third aim, during the semester, students completed two short writing assignments regarding political comedy. The first was an assessment of an editorial cartoon on the 2008 presidential campaign chosen by each student; the second was an analysis of The Daily Show. In both papers, students were asked to connect the humor to current events and explore any ideological messages conveyed. In the second paper, students were required to evaluate The Daily Show's utility as a political information source.

Regarding my fourth goal, I collected various data throughout the semester to gauge student response (although I focus here on data addressing student engagement). I distributed an anonymous survey near the end of the semester (after students had submitted their final class paper) requesting student feedback on the class's integration of political comedy, with particular attention to The Daily Show. I received 31 responses from a total of 46 registered students, a response rate of $68 \%$. Several of the questions were drawn directly or modified slightly from a number of sources (Baumgartner and Morris 2006, 352-53, 363; Pew Research Center for the People and the Press 2004, 24; Rottinghaus et al. 2008, 288-89). I also analyzed student papers regarding The Daily Show. Thirty students (all of whom were at least 18 years of age and thus able to provide consent) allowed me to consider their papers in my analysis.

\section{Student Survey}

The arm of the data collection that most directly gauged student response to political comedy-particularly The Daily Show-in the course was a 22-item survey. Thirty-one of 46 registered students participated in this anonymous survey: $74 \%$ of the 31 respondents were female (the class population was $63 \%$ female), and $94 \%$ indicated that they were aged 21 years or younger, with the final two respondents being between 22 and 25 years old.

Obviously, humor is subjective, and political humor can be particularly tricky to navigate in any setting, let alone the classroom. Jon Stewart and company make no secret of their political leanings, ${ }^{3}$ and I expected that more conservative students would be more likely to object to the inclusion of such work in course content. However, I was pleasantly surprised on this point: when I examined bivariate relationships, the Spearman's rho correla- tions between students' ideological self-identifications (scored on a 5 -point scale ranging from "very conservative" to "very liberal," with 28 respondents providing an answer to this prompt) and assessments of the program were lower than I anticipated and did not achieve statistical significance. ${ }^{4}$ In response to a request for comments about using The Daily Show or other political comedy in class, only one of the two students who recommended that I avoid the program in future semesters self-identified as "conservative," while the other self-identified as "liberal." Instead, most student comments about the program's inclusion in the course were very positive, with the comments favoring an expansion of the comedy repertoire to other programs (with Colbert and Leno suggested as additional sources). In short, I was pleasantly surprised at how little ideological considerations appeared to influence students' reported receptiveness to the program's potential role in my introductory-level classroom.

More interestingly, 26 of the 31 respondents $(84 \%)$ indicated that they "occasionally" or "often" "learn[ed] something new about politics or current events" from The Daily Show (survey item slightly modified from an item used in Pew Research Center for the People and the Press 2004, 24). Numbers based on selfperceptions should be treated skeptically, given concerns expressed by Hollander (1995) and Baumgartner and Morris (2008), but these findings may be a basis for exploring pedagogical potential if we focus on pushing students to learn and think more in response to the comedy. In this vein, 27 respondents $(87 \%)$ answered "yes" when asked if watching the program "affected [their] interest in keeping up with and/or learning more about politics" (question based on Rottinghaus et al. 2008, 288-89), with all 27 indicating that this viewing provided encouragement for their enhanced engagement, rather than having any discouraging effect. This discovery is consistent with the findings of Feldman $(2007,423)$ and may offer another promising response to Baumgartner and Morris's concern that exposure to The Daily Show could lead to the avoidance of politics (2006, 362-63).

In evaluating the program's potential influence on students' interest in political involvement, only 1 of the 31 respondents indicated that viewing the program "discouraged" him from political involvement. Instead, 19 students (61\%) indicated that the program had a positive impact on their interest in political involvement, and $11(35 \%)$ asserted that the program had no impact in this area. Again, I see these numbers as possible responses to Baumgartner and Morris's (2006) concerns.

\section{(Re-)Examination of Student Papers}

The final paper assignment for this course asked students to analyze an episode of The Daily Show to examine its political content, including a researched discussion of the "current events" context of the humor, an assessment of the ideological perspective(s) put forward in the episode, and the usefulness of the program as a news source. Re-examining papers well after the close of the semester allowed me to look for themes or trends that may have escaped me in the throes of semester-end grading. A few noteworthy points came to my attention that may inform both future assignments and future explorations of teaching strategies.

One student's observation about the program seemed to bring my goals to fruition in noting that "although The Daily Show isn't the most truthful political news show, it does make people think more about issues. Jon Stewart uses humor to point out unique angles of criticism, which essentially forces viewers to see different 
views, some of which would have otherwise been overlooked." Such a perspective melds beautifully with Gettings's suggestion that, "if we can classify fake news as fiction, and if we can understand how fiction conveys truth, then we can understand how The Daily Show conveys real news to its viewers" $(2007,16)$. However, student responses to the program varied, as did the motivations of those who were already viewers. For example, while one young man credited the program with jumpstarting his own interest in politics even before he began college, another student stated that he viewed the program regularly despite his lack of interest in politics; rather, he watches The Daily Show because it plays several times a week on his favorite channel, Comedy Central. While this latter student might be a candidate for testing as a beneficiary of learning materials via Zinser's "slipping vegetables onto a pizza" theory of comedic education (2007), he also demonstrates that even regular viewing of The Daily Show may not necessarily spur greater political interest or involvement in all audience members.

\section{CONCLUSION}

Given the popularity and cultural clout of contemporary political satire works such as The Daily Show, we as political science instructors should be exploring how best to exploit the pedagogical potential of such smart, provocative, and readily available resources, which many of our students are no doubt already following. Actively engaging with such resources may assist in both stimulating student interest in our subject matter and allowing opportunities to push students to engage more critically with the familiar sources that already serve as cultural reference points.

\section{NOTES}

My thanks are due to Dr. Michael Comiskey, Dr. Stephen Nichols, Nicole Noel, Allen Risley, Dr. Tracey Renner, Dr. Garry Rolison, and Dr. Robert Yamashita for their assistance with various aspects of this project. An earlier version of this paper was presented at the 2009 meeting of the Midwest Political Science Association.

1. I have also seen one other unpublished manuscript in the review pipeline addressing political satire in assigned class readings. Like Baumgartner and Morris's 2008 study, this manuscript was also based on The Daily Show's textbook spinoff.

2. Baumgartner and Morris also note this issue $(2008,181)$.

3. As discussed previously, Stephen Colbert's portrayal of himself as a conservative pundit is far more complex and challenging for viewers to unpack (see Baumgartner and Morris 2007), and I did also use Colbert's clips in class. However, I did not include questions in this survey that were specific to The Colbert Report.

4. The Spearman's rho correlation between students' self-reported ideology and assessments of The Daily Show as "a useful source of political information" was .234 , and the correlation between ideology and assessments of the show's effectiveness "as a tool for learning about politics" was .214. Bearing in mind the limitations of statistical significance with such a small and nonrandom sample, it is worth noting that neither correlation achieved significance using even a one-tailed test with a significance cutoff of .10.

\section{REFEREN C E S}

Baum, Matthew A. 2002. "Sex, Lies, and War: How Soft News Brings Foreign Policy to the Inattentive Public." American Political Science Review 96 (1): 91-109.

- 2003a. "Soft News and Political Knowledge: Evidence of Absence or Absence of Evidence?" Political Communication 20: 173-90.

- 2003b. Soft News Goes to War: Public Opinion and American Foreign Policy in the New Media Age. Princeton, NJ: Princeton University Press.

Baumgartner, Jody, and Jonathan S. Morris. 2006. "The Daily Show Effect: Candidate Evaluations, Efficacy, and American Youth." American Politics Research 34 (3): $341-67$.
. 2007. "One 'Nation,' under Stephen? The Effects of The Colbert Report on American Youth." Paper presented at the Midwest Political Science Association Annual Meeting, April 12-15, Chicago, IL.

. 2008. "Jon Stewart Comes to Class: The Learning Effects of America (The Book) in Introduction to American Government Courses." Journal of Political Science Education 4: 169-86.

The Daily Show with Jon Stewart. 2010. Comedy Central. "About the Show." http:// www.thedailyshow.com/about.

Erion, Gerald J. 2007. "Amusing Ourselves to Death with Television News: Jon Stewart, Neil Postman, and the Huxleyan Warning." In The Daily Show and Philosophy: Moments of Zen in the Art of Fake News, ed. Jason Holt, 5-15. Malden, MA: Blackwell.

Feldman, Lauren. 2007. "The News about Comedy: Young Audiences, The Daily Show, and Evolving Notions of Journalism." Journalism 8 (4): 406-27.

Gettings, Michael. 2007. "The Fake, the False, and the Fictional: The Daily Show as News Source." In The Daily Show and Philosophy: Moments of Zen in the Art of Fake News, ed. Jason Holt, 16-27. Malden, MA: Blackwell.

Ginsberg, Benjamin, Theodore J. Lowi, and Margaret Weir. 2007. We the People: An Introduction to American Politics. 6th ed. New York: W.W. Norton.

Hollander, Barry A. 1995. "The New News and the 1992 Presidential Campaign: Perceived vs. Actual Political Knowledge.” Journalism and Mass Communication Quarterly 72 (4): 786-98.

Janda, Kenneth, Jeffrey M. Berry, and Jerry Goldman. 2009. The Challenge of Democracy: American Government in a Global World. 1oth ed. Boston: Wadsworth Cengage.

Kaplan, Robert M., and Gregory C. Pascoe. 1977. "Humorous Lectures and Humorous Examples: Some Effects upon Comprehension and Retention." Journal of Educational Psychology 69 (1): 61-65.

Kher, Neelam, Susan Molstad, and Roberta Donahue. 1999. "Using Humor in the College Classroom to Enhance Teaching Effectiveness in 'Dread Courses.” College Student Journal 33 (3): 400-06.

Korobkin, Debra. 1988. "Humor in the Classroom: Considerations and Strategies." College Teaching 36 (4): 154-58.

MacMullan, Terrance. 2007. "Jon Stewart and the New Public Intellectual." In The Daily Show and Philosophy: Moments of Zen in the Art of Fake News, ed. Jason Holt, 57-68. Malden, MA: Blackwell.

Norton, James. 2001. "Modern-Day History Lessons.” Flak Magazine, April 24 http://www.flakmag.com/jim/resume/sampled3.html.

Pew Research Center for the People and the Press. 2004. "Cable and Internet Loom Large in Fragmented Political News Universe." http://people-press.org/ reports/pdf/200.pdf.

_. 2006. "Online Papers Modestly Boost Newspaper Readership." http:// people-press.org/reports/pdf/282.pdf.

. 2008. "Key News Audiences Now Blend Online and Traditional Sources." http://people-press.org/reports/pdf/444.pdf.

Peyser, Marc, and Sarah Childress. 2003. "Red, White, and Funny." Newsweek, December 29, 70-77.

Pollak, Judy P., and Paul D. Freda. 1997. "Humor, Learning, and Socialization in Middle Level Classrooms." The Clearing House 7o (4): 176-78.

Prior, Markus. 2003. "Any Good News in Soft News? The Impact of Soft News Preference on Political Knowledge.” Political Communication 20: 149-71.

Rottinghaus, Brandon, Kenton Bird, Travis Ridout, and Rebecca Self. 2008. "'It's Better than Being Informed': College-Aged Viewers of The Daily Show.” In Laughing Matters: Humor and American Politics in the Media Age, eds. Jody C Baumgartner and Jonathan S. Morris, 279-94. New York: Routledge.

Stelter, Brian. 2007. “The Colbert Nation Quickly Colonizes Facebook.” New York Times, October 29, $\mathrm{C}_{4}$.

Stewart, Jon, Ben Karlin, and David Javerbaum. 2004. America (The Book): A Citizen's Guide to Democracy Inaction. New York: Warner.

Weaver, Richard L., II, and Howard W. Cottrell. 1988. "Motivating Students: Stimulating and Sustaining Student Effort." College Student Journal 22 (1): 22-32.

Young, Dannagal G., and Russell M. Tisinger. 2006. "Dispelling Late-Night Myths: News Consumption among Late-Night Comedy Viewers and the Predictors of Exposure to Various Late-Night Shows." International Journal of Press/Politics 11: $113-34$.

Zinser, Jason. 2007. "The Good, the Bad, and The Daily Show." In The Daily Show and Philosophy: Moments of Zen in the Art of Fake News, ed. Jason Holt, 41-53. Malden, MA: Blackwell. 


\section{American Political Science Association}

\section{APSA Membership Opens Doors \\ Take Advantage of the Value of APSA Membership}

\section{As the the oldest,}

largest, and most

comprehensive

political science

society in the

world, APSA

\section{supports over}

14,000 members

in 70 countries and

advances

political science in

many ways.

\section{Open the door}

to your future.

Become an APSA

member!

\section{Offering Online Scholarship}

Scholarship is central to APSA membership. Current and recent back issues of all three APSA journals are available online to members through Cambridge Journals Online. Members can also gain access to the full historical collection through JSTOR subscriptions. Political Research Online (PROL), a collaborative project led by APSA and a consortium of political science and related associations, houses 30,000 searchable conference papers.

\section{Creating Networks and Connecting Scholars}

APSA strives to provide valuable opportunities for members to network with colleagues, share ideas, and form relationships to drive their careers. Members receive discounts for APSA conferences-the Teaching and Learning Conference, Conference for Chairs, and the Annual Meeting-as well as access to the association's Organized Sections.

\section{Providing Career and Employment Resources}

APSA's eJobs is the most comprehensive online resource of political science employment opportunities and job candidates. It is fully searchable and updated daily with new job listings and candidate resumes. The eJobs placement service at the Annual Meeting brings employers and candidates together in person to greatly facilitate the hiring process.

\section{Supporting Political Science Research}

The Centennial Center for Political Science \& Public Affairs, located at APSA's headquarters building, provides office space for scholars and students conducting field work in Washington, D.C.Through the Center, APSA also offers a number of research grant opportunities for scholars working in various subfields.

\section{Membership application, rates and details: www.apsanet.org/membership}

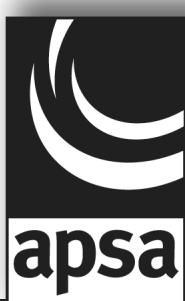

